JOURNAL OF SECURITY AND SUSTAINABILITY ISSUES

ISSN 2029-7017 print/ISSN 2029-7025 online

2019 June Volume 8 Number 4

http://doi.org/10.9770/jssi.2019.8.4(18)

Scopus

\title{
PROVIDING SECURITY FOR THE DEVELOPMENT OF HIGH-TECHNOLOGY ORGANIZATIONS
}

\author{
Vyacheslav Makedon ${ }^{1}$, Svetlana Drobyazko², Hanna Shevtsova ${ }^{3}$, Olha Maslosh ${ }^{4}$, Maryna Kasatkina ${ }^{5}$ \\ ${ }^{1}$ Oles Honchar Dnipro National University, Gagarin ave., 74, Dnipro city, Ukraine \\ ${ }^{2 *}$ Open International University of Human Development «Ukraine», 23 Lvivska Str., Kyiv, 03115, Ukraine \\ ${ }^{3}$ Institute of Industrial Economics of the National Academy of Sciences of Ukraine, 2, Marii Kapnist str., Kyiv, Ukraine \\ 4, 5 Volodymyr Dahl East Ukrainian National University, 59-a, Tsentralny ave., Severodonetsk, Ukraine \\ E-mail: ${ }^{2 *}$ drobyazko.s.i@gmail.com
}

Received 10 December 2019; accepted 10 May 2019; published 30 June 2019

\begin{abstract}
In scientific work the peculiarities of innovation processes in the activity of high-tech companies are determined. The functional and managerial components of ensuring the security of development of high-tech companies are determined on the basis of establishing centers of responsibility for the support of innovative projects. The model of support of sustainable innovation development is developed and the algorithm of formation of the structure of business of high-tech companies with the purpose of strengthening of organizational security of out-of-date development is offered. The recommendations on harmonization of innovation development and security of commercial activity for high-tech companies are given.
\end{abstract}

Keywords: development security; high-technology organizations; technology business; innovation process; responsibility center; innovation project; business structure; R\&D

Reference to this paper should be made as follows: Makedon, V.; Drobyazko, S.; Shevtsova, H.; Maslosh, O.; Kasatkina, M. 2019. Providing security for the development of high-technology organizations, Journal of Security and Sustainability Issues 8(4): 759-774. http://doi.org/10.9770/jssi.2019.8.4(18)

JEL Classifications: O11, O32

\section{Introduction}

The most important factor in securing the development of high-tech companies is effective management. In the economy of the leading countries of the world there is a steady tendency of the growth of the role of high-tech, resource-saving technologies and industries. The undisputed evidence of the domination of such a direction of safe economic development is, on the one hand, the fact that the most expensive companies in the world, whose shares are quoted in the stock market, are not the largest resource-extracting and processing companies, but those who specialize in intellectual, science-intensive, high-tech products, and on the other hand, those that consistently reduce the specific energy consumption per unit of output and its prices.

Currently, in all developed countries, an active search for social and organizational changes is being implemented that will open up new ways of life and consumption, and will allow to weaken or completely remove institutional barriers to the spread of new technological improvements. The problem of ensuring the security of development and innovation management within the national economy and the management of high-tech structures and companies is sufficiently broadly presented in the work of a number of research scientists (Akman, and Yilmaz (2008); David, (2015); Freeman (2002); Grant (2010); Kogabayev and Maziliauskas (2017); Lawson and Samson (2001); Nuryakin, at. (2018); Powell (2017); Tidd and Bessant, (2013); Von Hippel (2008); Tvaronavičienè (2018); Havierniková, Kordoš (2019)). 
But at the same time, most of the scientists try to determine the causes of the failures of forming the innovation vector of the economy, the emergence of challenges for commercial security, the perspective directions of reform and changes in the management system of high-tech industries and companies. These provisions are the basis for the study of the role of high-tech companies in the world economy and the definition of problem points, socio-economic components that impede the rapid introduction of innovative production technologies and management in the company's management system and enhance the innovation activity in the economy of the country.

The aim of the study is to identify problems and obstacles in the security of sustainable development and management of high-tech structures and companies, identify urgent measures and programs in order to enhance and strengthen the role of innovation in industries in order to move to the concept of safe innovation development.

\section{Science-based companies: the essence and formation}

In the leading industrialized countries of the world, the approach to innovation development, called the innovative explosion or a complex of interconnected innovations, is particularly striking. This approach was suggested by a researcher (Rivera (2017)) and it is based on the fact that innovations for a company operating in the international market of products and services should be considered as a continuous process that affects various aspects of its activities (Figure 1).

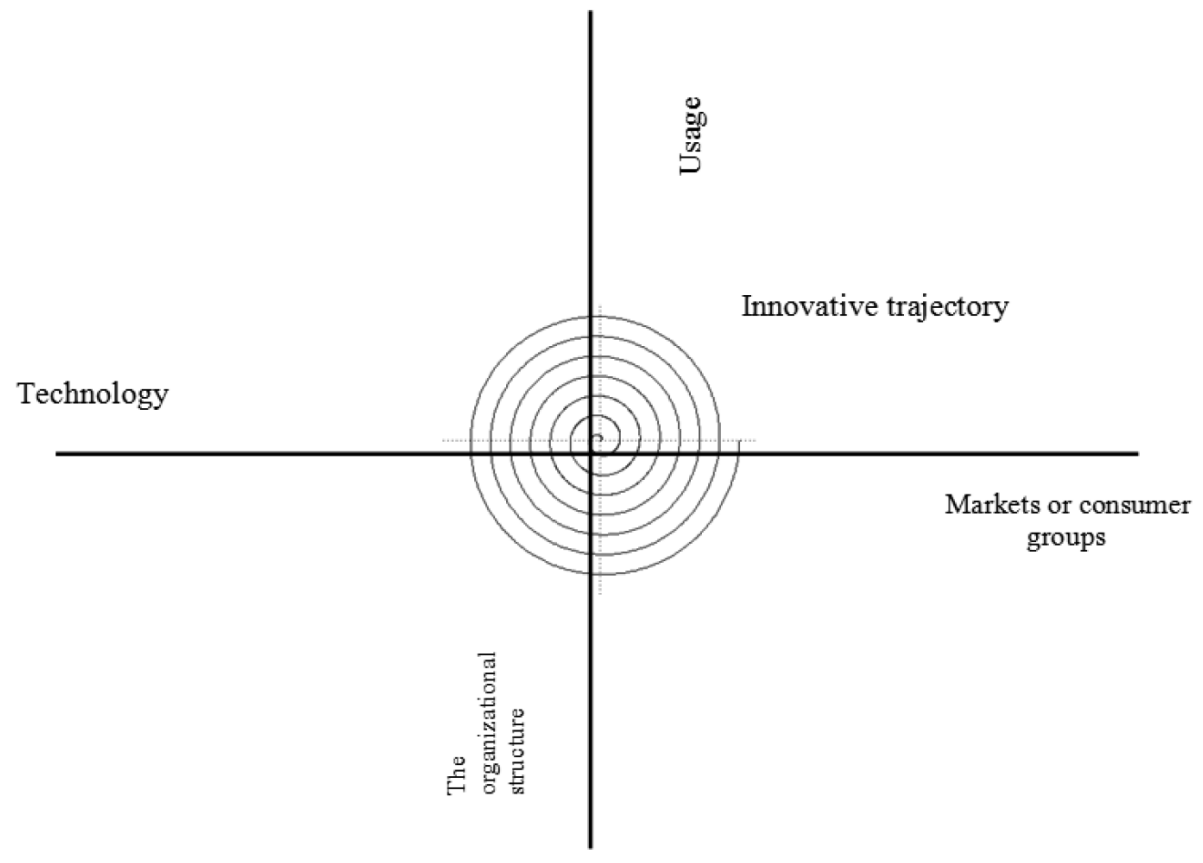

Figure 1. Innovation process within high-tech companies

Source: Rivera, 2017

Innovation is considered to be the main path for sustainable growth and safe development. With the help of innovation, that is, the introduction of new technology into the world market (T), application in the form of new goods and services (A), the formation of new markets (M) and / or the introduction of new organizational forms $(\mathrm{O})$, the final value for consumers, and first of all, their loyalty is aggravated (Ortt et al. (2008); Limba T., Agafonov K., Paukštė L., Damkus, M., Plèta T. (2017)).

The affiliation of the branches of the economy to the category of high-tech is characterized by the world practice of the indicator of the science-intensive production, which is determined by the ratio of the amount of expenditures on R\&D (Research \& Development - VR\&D) to the volume of gross production in this industry 
(VVP) (Best (2013)):

$$
\frac{\mathrm{V}_{R \& D}}{\mathrm{~V}_{\text {ВП }}} \times 100 \%
$$

It is generally accepted that for high-tech industries, this figure should be 1,2-1,5 or more times higher than the average for the manufacturing industry. For example, in the US, the most high-tech industries recognized: the aerospace complex - 19\%, the radio industry - 7\%, the machine-building industry $-4.8 \%$ (World Bank national accounts data, and OECD National Accounts data files).

Specific features of the organization, management and management of high-tech industries are:

complex nature of the company's activity, which requires solving all the problems of engineering: from scientific research to serial production;

combination of the target orientation of research, development and production for a concrete result with perspective directions of work of system-wide, fundamental purpose;

high scientific and technical level of manufactured products;

a significant proportion of R\&D spending;

the domination of the process of technology change over stationary production and the consequent need for a regular update of core production assets, the development of experimental and experimental base;

polytechnicity of research and development, diversification and multi-nomenclature of production;

high dynamics of development of production, realized in the constant updating of its elements (objects of research, development and production, technologies, circuit and design decisions, information flows), the change in quantitative and qualitative indicators, which complicates the problem of uniform loading and use of production potential;

branched internal and inter-industry cooperation caused by the complexity of high-tech products and specialization companies;

a high degree of uncertainty (entropy) in the management of state of the art development, which requires the use of predictive technology estimates for the future when making decisions. Creation of qualitatively new products, as a rule, is carried out in parallel with the development of the main components (circuit and design decisions, physical principles, technologies, etc.). Achievement of the given technical and economic parameters of this production is characterized by a high degree of scientific and technical risk in the general case. The risk of creating new components of the system determines a strategy based on research in fundamental and applied science and technology, on the development of alternatives to components. However, this strategy can lead to a significant increase in the cost of resources, the feasibility of which is not always justified;

intensive investment process, which is the most important factor in achieving the goals of research and development of high scientific and technical level, which accompanies the implementation of large projects;

the presence of unique teams with a large share of scientists, highly skilled engineering workers and industrial and industrial personnel in the total number employed in development and production (Barberis at. (2017); Janssen, at. al. (2015)).

The analysis of studies in this format showed that most high-tech companies in developing countries identified the most significant problems of entrepreneurial activity and commercial security: high tax burden, limited financial resources, instability of the legal framework, and lack of certainty of the requirements of the legislation that creates conditions for them. poor-quality interpretation (Figure 2). 


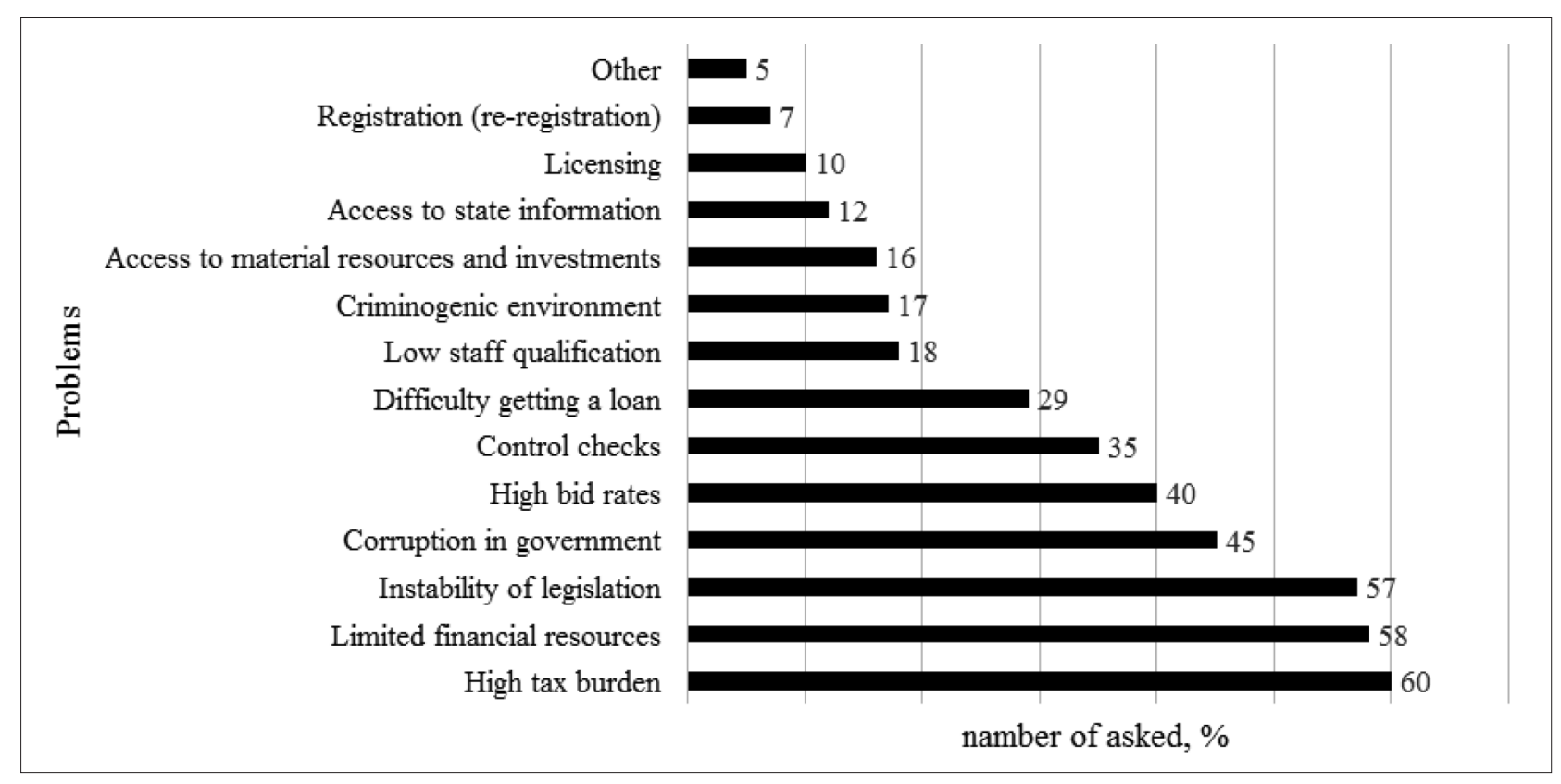

Figure 2. Common problems and challenges to the security of commercial activity of high-tech companies in developing countries

Source: World Bank national accounts data, and OECD National Accounts data files

The transition from the economic crisis to revival and recovery requires ahead of investment growth primarily in the active part of fixed assets and renewal of fixed assets at the latest technological base. The latest technological base in the state economy is determined by the technology and technology of the fourth, fifth and sixth technological phases and the absence of the first three stages. At the same time under the technological system is understood the totality of technical systems and technological processes that express a certain generation (level) of scientific and technological development.

Therefore, one of the main tasks of activating innovation activity is to renew capital at the latest technological base.

Each generation of technics, technology in its life cycle runs five phases (Wheelen and Hunger (2015)):

1. the origin of the idea;

2. its scientific and practical development;

3. development in the production, consumption and distribution, usage of sectors of production and consumption markets in a large number;

4. stable production with further improvement of the quality of technology and technology;

5. aging and crowding out of production and consumption, replacing new, more progressive and efficient generations.

Duration of the life cycle, depending on the type of technology and technology, the scope of its application, the rate of acceleration of the NTP is different and varies from several years to two or more decades.

The peculiarity of the general trend of generational change is that the last phase of the cycle of the generation, and the first phases of the cycle of generations that come, coincide in time. The analysis of world experience shows that the mass replacement of generations of technology and technology occurs once every decade and underlies the medium-term cycles of technological devices and periodic crises. Technological crises are characterized by deterioration of the quality parameters of products and technologies used, due to their moral aging, the appearance of pseudo-innovations. The crisis phase of medium-term technological cycles usually lasts a year or two and is overcome as the technology and technology of the new generation. 
The crisis with the change of technological devices is deeper, if it coincides with the crisis in the economy. Its characteristic features are low efficiency of the latest generation of devices, and negative changes in the structure of the economy (Bagno et al. (2017)).

At present, there is an industrial development of the sixth technological device, which includes nanoelectronics, genetic engineering, multimedia interactive information systems, high-temperature superconductivity, and the like. So in the US, the process of turning inventions and scientific results into a successful technological business is extremely developed. Exports of high-tech products bring about $\$ 700$ billion to the United States. year, Germany 530, Japan - 400 (OECD Main Science and Technology indicators).

World experience shows that financing of design and development of new technologies due to significant risks can not be sufficiently carried out at the expense of the state. Therefore, the role of such investors in the world is often venture capital funds that can take risks for the sake of high profits from the implementation of successful projects that compensate for unsuccessful investments. There are more than 900 venture companies in the United States, which annually invest \$ 35 billion in innovative projects. A similar pattern is observed in other developed countries (Čirjevskis (2016)). According to statistics, only one of 100 proposals to the venture fund receives funding and only $30 \%$ of the financed projects in three years - five years are successful. The profit of the venture capitalist is $10-15 \%$ higher than the bank interest rate (OECD Main Science and Technology indicators).

However, the expanded reproduction of hi-tech technologies requires the creation of such an economic environment in which the effect of their application manifested itself and would have a stimulating effect on all technological reprocessing of the final product. In order to achieve such a result, it is necessary to use systematic methods of management and stimulation of transition processes to new technologies and safe development.

\section{Formation of the structure of business in the management system of high-tech company}

We believe that the formation of a business structure in the management system of a high-tech company should include the allocation of responsibility centers. Under the center of responsibility (CS), it is understood as a segment inside the company, where it is expedient to accumulate information about costs and results of activities and headed by the responsible decision-maker. Construction of a business structure of companies based on the centers of responsibility and effective management of them is possible only with a clear formulation of tasks and the division of competences, which allows you to assign responsible for the results of activities. The main rule used by a high-tech company in determining the effectiveness of the CBA is: "You can answer for what you can directly influence.»

For the convenience of collecting data on costs and their analysis in the structure of the center of responsibility distinguish the place of occurrence of costs. Typically, these are jobs or spheres of activity that are part of the CBA, for which it is possible to keep a record of costs, but it is impractical (or impossible) to analyze the results of the activity (Barker, and Duhaime, 1997). Place of occurrence of costs (MVB) - a place or area of activity, where there were certain costs, where it is possible to initially register their magnitude.

Managing costs and outcomes at the centers of responsibility is aimed at satisfying the needs of internal planning and improving the effectiveness of companies in general. It should be noted that the structure of the centers of responsibility does not always coincide with the organizational structure of the company, as separate units can be divided into several centers of responsibility or, conversely, several units are united in one responsibility center (Holtzman (2008)).

Features of the management system by the centers of responsibility are as follows:

- determination of the area of authority and responsibility of each manager (the manager is responsible only for those indicators that he can control, which may be affected);

- personalization of documents of internal reporting; 
- the involvement of the managers of the responsibility centers in preparing the reports for the past period and plans (budgets) for the future period.

The choice of how the division of a high-tech company into the centers of responsibility is determined by the specifics of a particular situation. It is necessary to take into account the following requirements:

- availability of indicators for measuring the volume of activity;

- the responsible person who manages and is responsible for the activities of the CBA;

- clearly defined sphere of authority and responsibility of the manager of the CBA;

- the degree of detail is sufficient for analysis, but not excessive, so that keeping records is not too laborious;

1. The existence of any type of organization's cost of a CS, for which these costs would be direct (Basel and Brühl (2013)).

Traditionally, there are three types of $\mathrm{CV}$ which, in turn, can be classified in a number of subspecies:

1. Profit centers:

- investment centers;

- profit centers;

- Centers of revenue (income).

2. Service centers.

3. Cost centers:

- Centers of functional expenses;

- centers of general expenses (centers of liability) (Čirjevskis, A. (2016)).

The cost center structure is presented in Figure 3.

\begin{tabular}{|c|c|c|c|}
\hline Profit-center & Service-center & Cost center & Development center \\
\hline $\begin{array}{c}\text { Works on real market } \\
\text { prices with the } \\
\begin{array}{c}\text { income from external } \\
\text { circulation for market } \\
\text { companies }\end{array}\end{array}$ & $\begin{array}{c}\text { Estimated according to the data } \\
\text { on circulation in the domestic } \\
\text { market of companies at similar } \\
\text { prices to the market, called } \\
\text { "transfer prices" }\end{array}$ & $\begin{array}{c}\text { Carries out standard works } \\
\text { and is responsible only for } \\
\text { non-exceeding (or saving) } \\
\text { the planned costs, subject to } \\
\text { a certain amount of work }\end{array}$ & $\begin{array}{c}\text { The activities of this unit form the future } \\
\text { performance of companies; its activity } \\
\text { can be evaluated based on the results of } \\
\text { initiated innovation projects or the received } \\
\text { effects in their relationship with them }\end{array}$ \\
\hline
\end{tabular}

Figure 3. New components of organizational structure in high-tech companies

Source: Designed by the authors

The main feature of the profit center is that the given CB runs at real market prices, with the receipt of income from circulation from the external for the companies of the market. Profit centers can be formed according to different principles and criteria, which are selected in accordance with the changing market situation. In practice, the distribution of centers by products, regions, affiliates, countries, and types of customers has become widespread. Profit centers can interact with each other within the matrix of interconnections between several business areas. Cost centers perform standard work and can only be responsible for not exceeding (or saving) the costs planned for them, subject to a certain amount of work. They are characterized by strong integration into the structure of the company, the lack of need for customer search. Note that cost centers are able to meet only the costs that are regulated, the cost of which management can control and provide through the development of appropriate measures. This may be either costs associated with the operation of this CRO, or costs associated with the material provision of other divisions of companies. In the first case, CVs are referred to as «centers of functional costs,» in the second, «centers of total costs.»

In high-tech companies there are, as a rule, different directions of activity. This is due to the fact that companies that constantly carry out scientific and high-tech developments and maintain a high level of innovation, must abide by the conditions of profitability and liquidity. Therefore, the company, along with promising areas of high technical and technological level, have one or more fields of «supporting business» and, in addition, conduct a constant search on a long-term perspective on science and practice (Busse and Carl (2011)). 
For high-tech production, coordination of the work of the $\mathrm{CV}$ is especially important as each component of the organizational structure should not only fulfill its role, but also implement it in a strictly timed manner, defined in correlation with the current state and prospects of the activities of other CVs. At the same time, the question arises whether existing directions are profitable and promising for companies, and if so, what efforts are needed for their support or development.

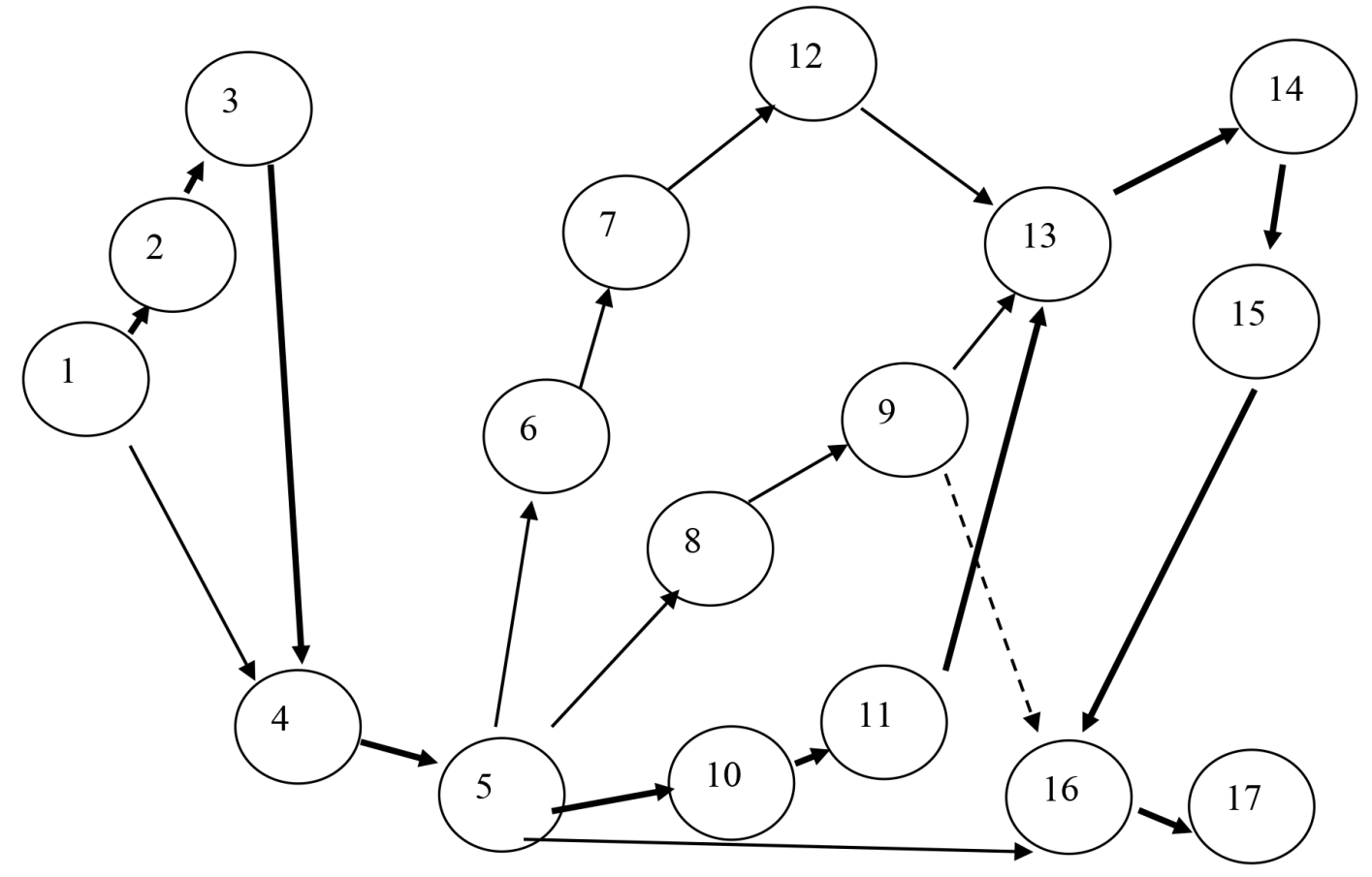

1. A proposal has been made for the production of a new product.

2. Approved study plan for a new product.

3. Technical conclusions are presented.

4. A product specification is prepared.

5. A decision was made about the possibility of producing a product.

6. A prototype is manufactured.

7. The production is completed.

8. Approved product testing plan

9. The results of the tests are presented and the decision on the presentation on the market is taken.

10. Composed budget sales.

11. Schedule of events and preparation of promotional materials for trial sale.

12. The production of a product for pilot sale has been completed.

13. Begin sale.

14. Finished sale.

15. Estimated sales results.

16. The decision was made to issue modified and technically advanced samples in the relevant market.

17. The production of modified and technically-completed samples in the relevant market has begun.

Figure 4. Diagram of the process of planning the work of centers for the development of international projects in a high-tech company

Source: Designed by the authors 
Moreover, prospects can be understood in different ways:

- as an ability to bring a significant profit for companies;

- as an ability to support other (more perspective directions) during their development;

- as an ability to create (maintain) the desired level of scientific and technical potential of companies, the bar of its innovation (Ireland, et al. (2013)).

In a high-tech company, there are necessarily auxiliary, service units not directly related to the development and production of products. According to the classification of the centers of responsibility listed above, they can be either categorized as service centers (if the volume of services provided by them or products can vary and CVs are able to affect their volume) or to cost centers (if the volume of services unchanged or not dependent on $\mathrm{CV}$ ).

But apart from the production units and the auxiliary service units for high-tech industries, the presence of development units, conducting research and design works, or on a permanent basis for manufacturers that are also active or currently in this state, is characterized by the presence of the former product this business line has entered a stage of aging, or perhaps it is a completely new business direction of the company. Most domestic companies, faced with the question of positioning such units (KB, development departments, etc.) in the structure of the international business of the company, classified them as «cost centers». In our opinion, this is not true, since the activities of these divisions form the future result of the company and, accordingly, their activities can be evaluated by the effects of initiated innovation projects, or, in any case, in their relationship with them. Therefore, it seems advisable to introduce high-tech industries of another category of CV-centers for the development of international projects (CDM) (Gomes and Wojahn (2017)).

Using the diagram (Figure 4), you can analyze the typical cycle of strategic planning in the CU of production - from the moment of the conception of a new product until the moment of its introduction into the market.

The activity of such CV forms the future performance of the company. Its activities can be evaluated by the effects of international initiated innovation projects or the resulting effects in their interactions.

In the beginning, the choice is made of the conceptual model of the organizational structure of the business. That is, the well-known linear-functional, divisional, matrix and design structures are analyzed. In the case if it is intended to select the units working in the future, then the decision on the formation of the RP is taken (Figure 5).

The following are considered variants of organization of activities of the CI. If the CI is to be organized on a permanent basis, an analysis of possible forms of integration of the CI into the organizational structure of the company is carried out. In case if the integration form is rejected by the decision of the company's management, then the project groups may be formed instead of the CR. In adopting a positive decision, the organizational structure of a high-tech company in the concept of CV with the allocation of CR is being developed.

The creation of high-tech companies with the focus on their own development in the structure of high-tech companies is particularly appropriate in Ukrainian business conditions, since research institutes and small innovative companies do not have interesting innovative proposals (Karpenko et al. (2018)). 


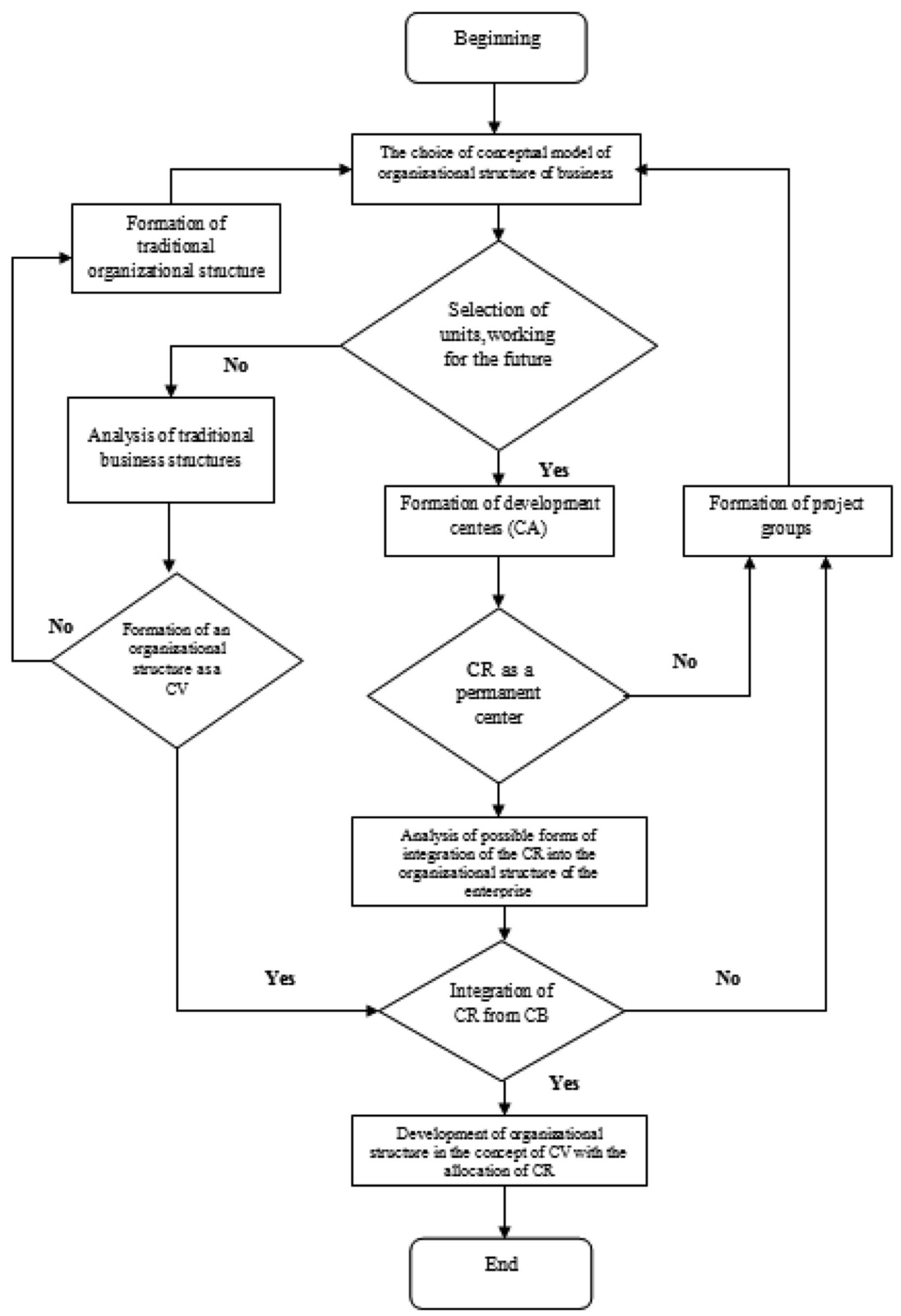

Figure 5. An algorithm for forming a business structure in a high-tech company

Source: Designed by the authors

Thus, the analysis made it possible to reveal a range of main problems of functioning and management of domestic high-tech organizations and companies. This as follows:

- lack of financial resources, which causes the search for sources of funding and rational use of those funds, due to the reasonability of choosing promising directions for innovation activity;

- the lack of a balanced distribution of company resources between current and strategic innovation activities;

- increased riskiness of innovation activity, caused both by small scale of the company and uncertainty of the result; 
- the need for systematic technological re-equipment of production by modern equipment;

- limited opportunities for marketing activities;

- imperfection of staff motivation, taking into account the increased importance of individual specialists (Tetiana et al. (2018)).

Thus, achieving success in the development of small business in the field of science-intensive is related to the need to address a number of important management problems, which should include:

- ensuring the balance of current and strategic innovation activities;

- increasing the reasonableness of choosing promising directions for innovation activity;

- provision of conditions for reducing the risks of innovative activity of high-tech companies;

- definition of rational financial and temporary conditions for the activation of innovation activity;

- assessment of the state and planning of innovative activity of high-tech companies;

Functional and structural description and consolidation of responsibility in the implementation of the management process for the development of small high-tech companies.

\section{Evaluation of the effectiveness of safe innovative development of high-tech company}

It should be noted the need to form a business management structure in a high-tech company, through the separation of the development center. The activity of such a development center forms the future performance. His activities can be evaluated by the effects of initiated innovation projects or the resulting effects in their relationship with Dobrovič, et. al 2018). In a high-tech company focused on the development of the internal structure of business management, it is necessary to allocate responsibility centers that have their own projects at a certain stage of development of the life cycle of a high-tech product. The presence in the structure of high-tech companies of development centers can realize the full innovation cycle: from research to commercialization.

Table 1 shows examples of R \& D structure and performance indicators for sustainable innovation development.

Table 1. Examples of indicators of the structure and performance of a safe innovative development of a high-tech company

\begin{tabular}{|l|l|}
\hline \multicolumn{1}{|c|}{ Structural indicators $\left(\mathrm{R}_{\mathrm{sk}}\right)$} & \multicolumn{1}{c|}{ Result indicators $\left(\mathrm{R}_{\mathrm{pl}}\right)$} \\
\hline $\mathrm{R}_{\mathrm{S} 1}$ - The degree of maturity of the project; & $\mathrm{R}_{\mathrm{P} 1}$ The quality of the result -; \\
\hline $\mathrm{R}_{\mathrm{S} 2}$ - Oversized inputs / phase of the project; & $\mathrm{R}_{\mathrm{P} 2}$ - Adherence to the terms; \\
\hline $\mathrm{R}_{\mathrm{S} 3}$ - Time of implementation of each phase of the project; & $\mathrm{R}_{\mathrm{P} 3}$ - Process speed; \\
\hline $\mathrm{R}_{\mathrm{S} 4}-$ The number of errors found during the project phases; & $\mathrm{R}_{\mathrm{P} 4}$ - Cost deviation; \\
\hline $\mathrm{R}_{\mathrm{s} 5}$ - Number of phases changes; & $\mathrm{R}_{\mathrm{P} 5}$ - Project costs (mastered and remaining); \\
\hline $\mathrm{R}_{\mathrm{S} 6}-$ The structure of the project staff; & $\mathrm{R}_{\mathrm{P} 6}$ - Expenses for error correction unproductive costs); \\
\hline $\mathrm{R}_{\mathrm{S} 7}-$ The proportion of costs to other organizations to the cost of the project & $\mathrm{R}_{\mathrm{p} 7}$ - Level of customer satisfaction. \\
\hline
\end{tabular}

Source: Designed by the authors

In R\&D projects, the target values of structural indicators stem from the goals and characteristics of projects. Target values of performance indicators are oriented towards product goals.

They document the entire customer, product requirements, product concept, design concept and production, as well as economic performance of the product (price, costs, sales, results and time of entry, target customers). The second component of the R\&D indicator is the measured values. These values are formed in the form of databases for projects (Prause (2016); Bezpalov, V.V., Fedyunin, D.V., Solopova, N.A., Avtonomova, S.A., Lochan, S.A. (2019)). 
In these databases, reflecting the entire package of works, the following numbers are given:

- dates of the beginning of the work package;

- the terms of the completion of the entire package of works;

- estimated working hours;

- consumption of materials;

- degree of readiness of the project at the time of measurement;

- quality of the result (Utterback (2004)).

With these six initial data, you can measure all metrics that are distributed in phases, with the exception of customer satisfaction. Below, in Table 2, as an example, a number of formulas for calculation of indicators based on data from a package are given.

Table 2. Formulas for calculation of indicators of structure and effectiveness of safe innovative development of high-tech company

\begin{tabular}{|c|l|}
\hline Indicators & \multicolumn{1}{c|}{ Formulas of calculation } \\
\hline $\mathrm{R}_{\mathrm{p} 1}$ (Quality of the result $)$ & $\begin{array}{l}\text { the number of work performed on the working package (RP) without alterations / total number of } \\
\text { works in the package; }\end{array}$ \\
\hline $\mathrm{R}_{\mathrm{p} 2}$ (Observance of the terms) $)$ & number of works without exceeding of terms / total number of works; \\
\hline $\mathrm{R}_{\mathrm{p} 3}$ (Process speed $)$ & The amount of work performed for the measuring period TO -T-1; \\
\hline $\mathrm{R}_{\mathrm{p} 4}$ (Cost deviation) & The number of works performed without exceeding the cost / total number of works in the package. \\
\hline
\end{tabular}

Source: Designed by the authors

Obtaining measurable values from the work pack has the advantage. Data on costs, terms, and quality go beyond the same object and at the same time. In doing so, the requirements for integration are fulfilled, ie the indicators are related to each other and are measured in synchrony with time and content. Work packages are available in all projects that apply project management methods.

If there are no packages, there is no successful program execution. Practice shows that the cost of getting the above initial data is minimal (Ushakov (2012); Dobrovolskienė, N.; Tvaronavičienè, M.; Tamošiūnienė, R. (2017)). It is usually sufficient to calculate packet values with a weekly or two-week interval. But the shorter the circle, the earlier you can detect the deviation from the target and correct them. The upper limit in terms is about four weeks.

On the basis of the analysis of the disadvantages of existing systems of indicators for assessing the effectiveness of $R \& D$, as well as based on the proposed systematization and the requirements set forth in , 


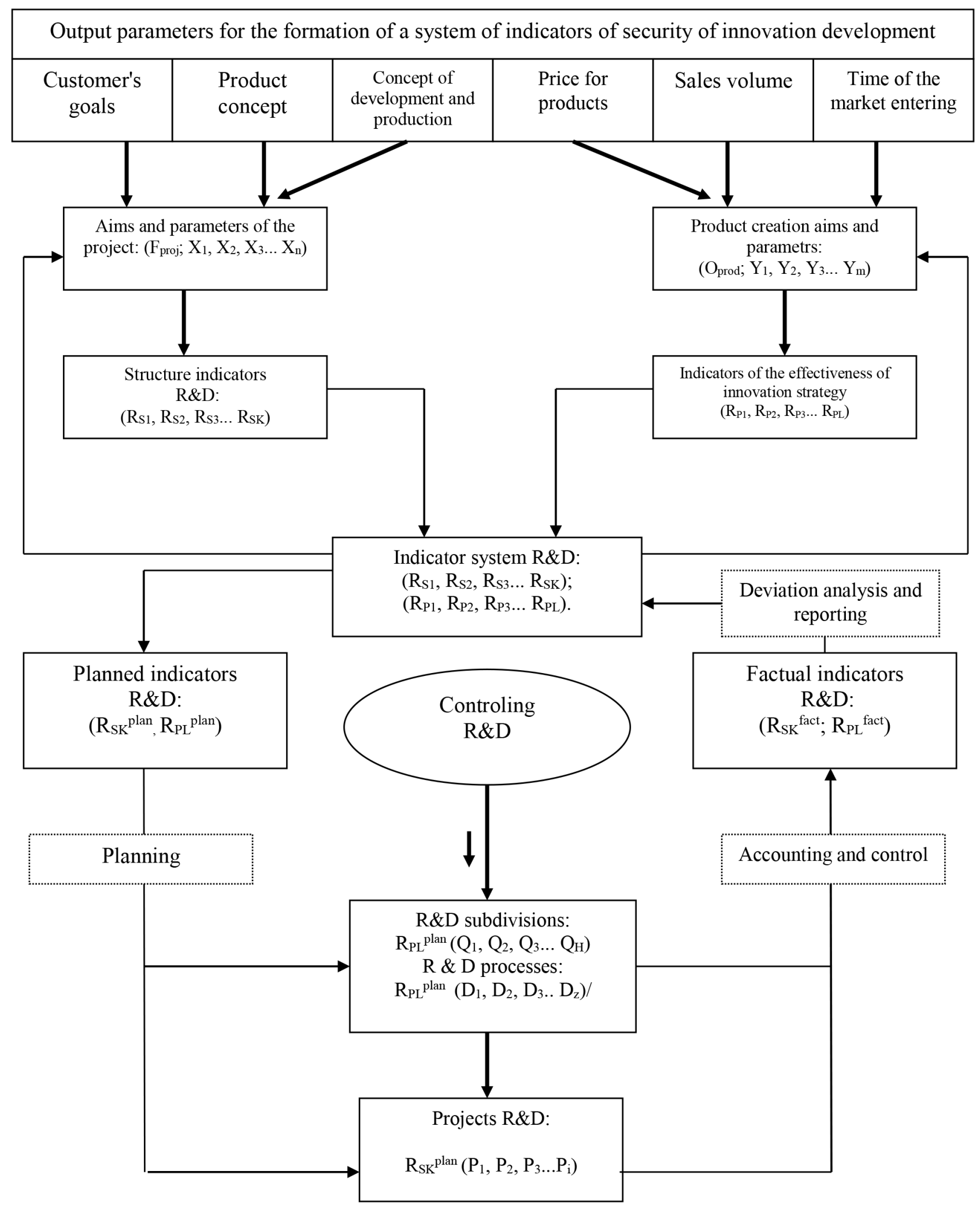

Figure 6. Structural-logical model of formation and interrelation of indicators of security of innovative development of high-tech company 
the work indicators, a methodical approach to the formation and interconnection of indicators of the performance of the sustainable innovation development of high-tech companies was substantiated in order to implement Rajnoha projects, and Lesníková, 2016). The main elements of the proposed approach are presented in Figure 6.

In the upper part of the model, the initial parameters for the formation of a system of R\&D indicators, on the basis of which the goals and parameters of the project (Fproj; X1, X2, X3 ... Xn) are formed, as well as the purposes of creating the product and its basic parameters (Oprod; Y1, Y2, Y3 ... Ym). On their basis, structure indicators (RS1, RS2, RS3 ... RSK) and performance (RP1, RP2, RP3 ... RPL) R \& D are formed.

Based on the purpose of the Fproj project and the purpose of creating the product Oprod, the planned indicators (RSKplan, RPLplan) R\&D are formed. It should be noted that the formation of planned indicators should be carried out with the direct support of the R \& D control unit, which will ensure a higher level of integration and coordination in the case of implementation of several R \& D at the same time.

Planned indicators are formed both in terms of subdivisions and processes - RPLplan (D1, D2, D3 .. Dz) / RPLplan (Q1, Q2, Q3 ... QH), and on projects - (RSKplan).

During the implementation of projects and processes by subdivisions, data on actual performance indicators (RSKfact; RPLfact) are presented, which are presented to the project manager in the form of a report with a mandatory interpretation of the results obtained.

After evaluating the results, an appropriate decision is made:

- in the case of fixing the allowable deviations for costs, terms, as well as reducing the likelihood of failure to achieve the specified technical parameters of the project, a decision is made to extend the project with appropriate adjustment of indicators;

-in the case of unacceptable deviations on the critical parameters of the project, a decision is made or substantial adjustment of the objectives and parameters of the project, as well as the purpose of creating the product, or the termination of the project

\section{Conclusions}

The necessity of introducing an algorithm for the formation of the structure of management of international projects in high-tech companies has been developed and substantiated, with the purpose of ensuring adequate commercial security, through the allocation of responsibility centers, namely, the profit center, service center, cost center, with the purpose of quality control of costs and results for international projects and contracts and satisfaction of internal planning needs, increase of company's efficiency on the world market of products.

The main feature of the profit center is that this CD operates on real market prices of the world market with the receipt of income from circulation from the international market. Centers of profit are limited in the adoption of international investment decisions and are not free in the formation of assets of high-tech companies, are valued at the magnitude of profit, taking into account the restrictions on assets. The result of the service center's activity is estimated according to the data on the domestic market of the company at prices similar to market ones, which are called «transfer prices». On this basis, the necessity of introducing for the high-tech manufactures of CD-centers of development of international projects (CRM) was substantiated. The presence in the structure of high-tech companies of the CIAM allows to realize a complete innovation cycle: from research to commercialization of international innovation projects.

In order to evaluate R\&D performance in the activities of high-tech companies, a methodological approach to the formation and interconnection of indicators of security performance of innovative development of a high-tech company with the purpose of realization of projects was proposed and substantiated. Indicators of the evaluation of the effectiveness of the implementation of an innovation project (project group) in order to stabilize development are formed. 


\section{References}

Akman, G. \& Yilmaz, C. (2008). Innovation capability, innovation strategy and market orientation: An empirical analysis in the Turkish software industry. International Journal of Innovation Management, 12, 69-111. https://doi.org/10.1142/S1363919608001923

Bagno, R.B., Salerno, M.S. \& Dias, A.V.C. (2017). Innovation as a new organizational function: Evidence and characterization from large industrial companies in Brazil. Production, 27. http://dx.doi.org/10.1590/0103-6513.207316

Barberis, S.. Roncallo, F., Traverso, A. (2017). Towards innovative district energy management: a case study with stochastic renewable generators, Entrepreneurship and Sustainability Issues 4(3): 294-309. http://dx.doi.org/10.9770/jesi.2017.4.3S(5)

Barker, V.L. \& Duhaime, I.M. (1997). Strategic change in the turnaround process: Theory and empirical evidence. Strategic Management Journal, 18(1), 13-38. https://doi.org/10.1002/(SICI)1097-0266(199701)18:1\%3C13::AID-SMJ843\%3E3.0.CO;2-X

Basel, J.S. \& Brühl, R. (2013). Rationality and dual process models of reasoning in managerial cognition and decision making. European Management Journal, 31(6), 745-754. http://dx.doi.org/10.1016/j.emj.2013.07.004

Best, R.J. (2013). Market-based management (Sixth Edition). Strategies for growing customer value and profitability. URL: https:// ru.scribd.com/doc/243775529/market-based-management-6th-edition-by-Roger-Best

Bezpalov, V.V., Fedyunin, D.V., Solopova, N.A., Avtonomova, S.A., Lochan, S.A. (2019). A model for managing the innovation-driven development of a regional industrial complex. Entrepreneurship and Sustainability Issues, 6(4), 1884-1896. http://doi.org/10.9770/ jesi.2019.6.4(24)

Busse, C. \& Carl, M.W. (2011). Innovation management of logistics service providers. International Journal of Physical Distribution \& Logistics Management, 41(2), 187-218. https://doi.org/10.1108/09600031111118558

Čirjevskis, A. (2016). Sustainability in information and communication technologies’ industry: innovative ambidexterity and dynamic capabilities perspectives, Journal of Security and Sustainability Issues 6(2): 211-226. http://dx.doi.org/10.9770/jssi.2016.6.2(2)

David, F.R. (2015). Strategic management: Concepts \& cases (Fifteenth Edition). Pearson Education Limited, England. URL: https:// www.academia.edu/36377580/Strategic_Management_Concepts_and_Cases_15th_Edition

Dobrovič, J., Urbański, M., Gallo, P., Benková, E., Čabinová, V. (2018). Balanced scorecard concept as a tool of strategic management and its usage in the construction industry. Polish Journal of Management Studies, 18 (2), 59-72. http://doi.org/10.17512/ pjms.2018.18.2.05

Dobrovolskienè, N.; Tvaronavičienė, M.; Tamošiūnienė, R. (2017). Tackling projects on sustainability: a Lithuanian case study, Entrepreneurship and Sustainability Issues 4(4): 477-488. http://doi.org/10.9770/jesi.2017.4.4(6)

Freeman, C. (2002). The Economics of Industrial innovation. London: Frances Pinter URL: https://ideas.repec.org/a/eee/irlaec/v3y1983i2p210-211.html

Gomes, G. \& Wojahn, R.M. (2017). Organizational learning capability, innovation and performance: Study in Small and Medium-Sized Enterprises (SMES). Re vista de Administração, 52, 163-175. https://doi.org/10.1016/j.rausp.2016.12.003

Havierniková, K.; Kordoš, M. 2019. Selected risks perceived by SMEs related to sustainable entrepreneurship in case of engagement into cluster cooperation, Entrepreneurship and Sustainability Issues, 6(4), 1680-1693. http://doi.org/10.9770/jesi.2019.6.4(9)

Holtzman, Y. (2008). Innovation in research and development tool of strategic growth. Journal of Management Development, 27(10), 1037-1052. URL: https://www.anchin.com/uploads/1406/doc/Pub_2010_RD_AdvTopics_Innovation.pdf

Grant, R.M. (2010). Contemporary strategy analysis (Seventh Edition). John Wiley \& Sons, Ltd., New York. URL: https://www.academia.edu/17604214/Contemporary_Strategy_Analysis_Text_Only_7e

Ireland, R.D., Hoskisson, R.E. \& Hitt, M.A. (2013). Strategic management: Competitiveness and globalization (Tenth Edition). Cincinnati: Cengage Learning. URL: https://shabbiroffice.files.wordpress.com/2017/01/strategic-managment-concept-and-case-by-hitt.pdf

Janssen, M., Stoopendaal, A.M.V. \& Putters, K. (2015). Situated novelty: Introducing a process perspective on the study of innovation. Research Policy, 44(10), 1974-1984. https://doi.org/10.1016/j.respol.2015.06.008

Karpenko, L.; Serbov, M.; Kwilinski, A.; Makedon, V. \& Drobyazko, S. (2018). Methodological platform of the control mechanism with the energy saving technologies, Academy of Strategic Management Journal, Volume 17, Issue 5 URL: https://www.abacademies.org/ articles/Methodological-platform-of-the-control-mechanism-1939-6104-17-5-271.pdf 
Kogabayev, T. \& Maziliauskas, A. (2017). The definition and classification of innovation. Holistica, 8(1), 59-72. https://doi.org/10.1515/ hjbpa-2017-0005

Lawson, B., Samson, D. (2001). Developing innovation capability in organizations: a dynamic capabilities approach, International Journal of Innovation Management 3(5), 377-400. URL: https://pdfs.semanticscholar.org/ab85/1aee60231752a31721f727ab1fd3f74b 39a1.pdf

Limba T., Agafonov K., Paukštė L., Damkus, M., Plèta T., (2017). Peculiarities of cyber security management in the process of internet voting implementation, Entrepreneurship and Sustainability Issues 5(2): 368-402. http://doi.org/10.9770/jesi.2017.5.2(15)

Nuryakin, N.; Aryanto, V.D.W. \& Setiawan, M.B. (2018). Mediating effect of value creation in the relationship between relational capabilities on business performance. Contaduría y Administracion, 63(1), 1-21. UR1: https://ideas.repec.org/a/nax/conyad/v63y2018ilp33-34.html

OECD Main Science and Technology indicators. Available on the Internet: www.oecd.org/dataoecd/49/45/24236156.pdf

Ortt, J.R., Patrick, A. \& Van der, D. (2008). The evolution of innovation management towards contextual innovation. European Journal of Innovation Management, 11(4), 522-538. https://doi.org/10.1108/14601060810911147

Prause, G. (2016). E-Residency: a business platform for Industry 4.0?, Entrepreneurship and Sustainability Issues 3(3): 216-227. http:// dx.doi.org/10.9770/jesi.2016.3.3(1)

Powell, T.C. (2017). Strategy as diligence: Putting behavioral strategy into practice. California Management Review, 59(3), 160-190. https://doi.org/10.1177\%2F0008125617707975

Rajnoha, R., Lesníková, P. (2016). Strategic Performance Management System and Corporate Sustainability Concept - Specific Parametres in Slovak Enterprises, Journal of Competitiveness 8(3): 107-124. https://doi.org/10.7441/joc.2016.03.07

Rivera, M.J. (2017). Leveraging innovation \& intrapreneurship as a source for organizational growth. International Journal of Innovation Science, 9(2), 137-152. https://doi.org/10.1108/IJIS-12-2016-0057

Tetiana, H., Karpenko, L., Fedoruk, O., Shevchenko, I., \& Drobyazko, S. (2018). Innovative methods of performance evaluation of energy efficiency project. Academy of Strategic Management Journal, 17(2), 112-110. URL: https://www.abacademies.org/articles/ innovative-methods-of-performance-evaluation-of-energy-efficiency-projects-7067.html

Tidd, J. \& Bessant, J. (2013). Managing innovation: Integrating technological, market and organizational change (Fifth Edition). John Wiley \& Sons. URL: https://www.wiley.com/en-us/Managing+Innovation\%3A+Integrating+Technological\%2C+Market+and+ Organizational+Change $\% 2 \mathrm{C}+5$ th + Edition-p-9781118360637

Tvaronavičienė M. (2018). Towards internationally tuned approach towards critical infrastructure protection. Journal of Security and Sustainability Issues, 8(2), 143-150. https://doi.org/10.9770/jssi.2018.8.2(2)

Ushakov, D.S. (2012). Innovative capacity as a modern factor of countries investment attractiveness dynamic. International Journal of Organizational Innovation, 4(4), 6-20. URL:

http://www.ijoi-online.org/attachments/article/38/FINAL_ISSUE_VOL_6_NUM_3_JANUARY_2014.pdf

Utterback, J.M. (2004). Mastering the Dynamics of Innovation: How Companies Can Seize Opportunities in the Face of Technological Change. Boston: Harvard Business School Press URL: https://archive.org/details/masteringdynamic00utte

Von Hippel E. (2008). The Sources of Innovation. New York: Oxford University Press. UR1:

http://web.mit.edu/evhippel/www-old/books/sources/SofI.pdf

Wheelen, T.L. \& Hunger, J.D. (2015). Strategic management and business policy: Concepts (Fourteenth Edition). Pearson/Prentice Hall. URL: https://proeunthat.files.wordpress.com/2013/11/concepts-in-strategic-management-business-policy.pdf

World Bank national accounts data, and OECD National Accounts data files. Available on the Internet: http://data.worldbank.org/ indicator/NY.GDP.MKTP.CD?locations=LT 
Short biographical note about the contributors at the end of the article:

Vyacheslav MAKEDON, Dr. Hab. (Economics), Associate Professor, Oles Honchar Dnipro National University

ORCID ID: orcid.org/ 0000-0001-8131-0235

Svetlana DROBYAZKO, Candidate of Economic Sciences, Professor Department of Finance and Accounting, Open International University of Human Development «Ukraine», Kiev

ORCID ID: orcid.org/0000-0003-2022-0126

Hanna SHEVTSOVA, Doctor of Economic Sciences, Associate Professor, Department of Regulatory Policy and Entrepreneurial Development, Institute of Industrial Economics of the National Academy of Sciences of Ukraine

ORCID ID: orcid.org/0000-0003-3960-5296

Olha MASLOSH, PhD, Associate Professor Department of Economics and Intrepreneurship, Volodymyr Dahl East Ukrainian National University, Severodonetsk, Ukraine

ORCID: ID: orcid.org/0000-0002-0103-7011

Maryna KASATKINA, Assistant Professor Department of Economics and Entrepreneurship, Volodymyr Dahl East Ukrainian National University, Severodonetsk, Ukraine

ORCID ID: https://orcid.org/0000-0002-7053-1232 